\title{
DRUG RECEPTORS
}

R.D.R.-A 


\title{
BIOLOGICAL COUNCIL \\ The Coordinating Committee for Symposia on Drug Action
}

\section{DRUG RECEPTORS \\ A Symposium}

\author{
Edited by \\ H. P. RANG \\ Department of Physiology and Biochemistry \\ University of Southampton
}

Macmillan Education 
(C) Institute of Biology Endowment Trust Fund 1973

Softcover reprint of the hardcover 1st edition 1973 978-0-333-11242-7

All rights reserved. No part of this publication may be reproduced or transmitted, in any form or by any means, without permission

First published 1973 by

THE MACMILLAN PRESS LTD

London and Basingstoke

Associated companies in New York Melbourne

Dublin Johannesburg and Madras

SBN 333112423

ISBN 978-1-349-00912-1 ISBN 978-1-349-00910-7 (eBook)

DOI 10.1007/978-1-349-00910-7

Set in Great Britain by

Adlard \& Son Ltd

Bartholomew Press, Dorking 


\section{Biological Council}

Coordinating Committee for Symposia on Drug Action

Report of a symposium held on 17 and 18 April 1972

in London

at The Middlesex Hospital Medical School

Sponsored by

British Pharmacological Society

and

Biochemical Society

British Society for Immunology

Physiological Society

Royal Society of Medicine

Society for Drug Research

Society for Endocrinology

Society for Experimental Biology

Society of Chemical Industry (Pesticides Group)

Society of Chemical Industry (Physicochemical and Biochemical Panel)

Organized by a symposium committee consisting of

H. P. Rang (Chairman and Hon. Secretary)

Edith Bülbring

A. W. Cuthbert

L. T. Potter 


\section{FOREWORD}

The idea of a symposium on Drug Receptors was suggested to me in 1971 by the Biological Council's Coordinating Committee for Symposia on Drug Action. At that time the field had been rather static for several years but a few preliminary notes had just appeared which suggested that cholinergic receptors could be specifically labelled by means of radioactive snake toxins (cobra toxin and $\alpha$-bungarotoxin in particular). Moreover, the electric organs of various fish, such as the eel (Electrophorus) and the ray (Torpedo) had been shown to provide a much richer source of cholinergic receptor material than was available hitherto. The unholy alliance of these two warlike creatures, the cobra and the electric eel (which Nature has mercifully contrived to keep apart) seemed certain to lead to rapid developments in the time intervening between the planning stage and the meeting itself in April 1972. We were not disappointed. In the final session Dr J.-P. Changeux withdrew with a flourish from his breast pocket a tiny glass tube with a distinct blue band across it - the receptor protein displayed before our very eyes!

Our aim in planning the programme was to try to bring together the various separate approaches that have been used to study drug receptors.

The symposium therefore includes work by pharmacologists on the classification of receptors by the use of antagonists, by electrophysiologists on the characterization of the ionic permeability changes caused by neurotransmitters, and by biochemists on the labelling and isolation of receptor macromolecules. One of the most promising meeting-points is, in my opinion, the application to drug-receptor mechanisms of ideas that have been developed in relation to enzyme regulation. Ten years ago, in spite of the fact that the algebraic description of drug-receptor interactions was virtually identical to that of enzyme kinetics, the two problems seemed to be a long way apart, because enzyme molecules were thought of as rigid structures which acted on, but did not respond to, substrate molecules. Receptors, on the other hand, had to be flexible and responsive to the binding of small molecules. During the last few years, though, the two have converged to the point of collision, mainly because of the increasing emphasis in enzymology of the importance of flexibility in enzyme molecules, and of conformational changes brought about by the attachment of small molecules. This coming together of biochemistry and pharmacology, and the use of theories developed for allosteric enzyme regulation to explain certain kinds of drug action, is a recurring theme of the papers that were presented.

The symposium is entitled Drug Receptors, but the word 'drug' does not really convey the meaning properly. What we need is a word for any small molecule-whether it be a neurotransmitter, a hormone, an allosteric regu- 
latory substance or a synthetic drug-which reacts with a specific site on a macromolecule and thereby modifies the macromolecule so as to alter its functional properties. Perhaps some spare-time lexicographer will present us with the mot juste, so that we can communicate more freely. Until then, 'drug' at least has the merit of being short.

This symposium was one of a highly successful series organized by the Biological Council. It attracted an audience of nearly six hundred, and I must here express my thanks, particularly to Miss G. M. Blunt for organizing this large and complicated meeting virtually single-handed, and also to the Wellcome Trust for their generosity in providing a grant which enabled us to invite speakers from many parts of the world.

H. P. RANG

Southampton

November 1972 


\section{CONTENTS}

Foreword

List of Participants

1. BülBRING, EDITH. Action of catecholamines on the smooth muscle cell membrane

2. Haylett, D. G. and Jenkinson, D: H. Actions of catecholamines on the membrane properties of liver cells

3. SCHILD, H. O. Receptor classification with special reference to $\beta$-adrenergic receptors

4. Kerkut, G. A., Lambert, J. D. C. and Walker, R. J. The action of acetylcholine and dopamine on a specified snail neurone -

5. Gerschenfeld, H. M. and Paupardin, Danielle. Actions of 5-hydroxytryptamine on molluscan neuronal membranes

6. KeHOE, JACSUE. Acetylcholine receptors in Aplysia neurones.

7. Bolton, T. B. The permeability change produced by acetylcholine in smooth muscle

8. MagazaniK, L. G. and VyskočIL, F. Desensitization at the motor endplate

9. TheSLEFF, S. Functional properties of receptors in striated muscle

10. PoDlesKI, T. R. Cooperativity of the electroplax membrane .

11. Colquhoun, D. The relation between classical and cooperative models for drug action

12. Singer, S. J., RUoho, A., Kiefer, H., Lindstrom, J. and LenNoX, E. S. The use of affinity labels in the identification of receptors .

13. Karlin, A., Cowburn, D. A. and Reiter, M. J. Molecular properties of the acetylcholine receptor . . . . .

14. Fewtrell, C. M. S. and Rang, H. P. The labelling of cholinergic

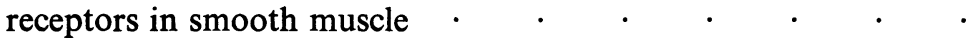

15. Barnard, E. A., Chiu, T. H., Jedrzejcyzk, J., Porter, C. W. and WIECKOWSKI, J. Acetylcholine receptor and cholinesterase molecules of vertebrate skeletal muscles and their nerve junctions

16. O'Brien, R. D., Eldefrawi, M. E. and Eldefrawi, A. T. The isolation of functional acetylcholine receptor . . . .

17. De Robertis, E. The isolation and molecular properties of receptor proteolipids

18. Changeux, J.-P., Meunier, J.-C., Olsen, R. W., Weber, M., Bourgeois, J.-P., Popot, J.-L., Cohen, J. B., Hazelbauer, G. L. and LesTER, H. A. Studies on the mode of action of cholinergic agonists at the molecular level

19. POTTER, L. T. Acetylcholine receptors in vertebrate skeletal

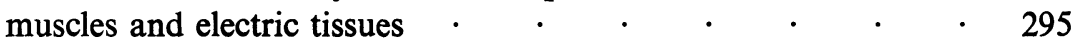




\section{LIST OF PARTICIPANTS}

E. A. Barnard, Department of Biochemical Pharmacology, State University of New York, Buffalo, N.Y. 14214, U.S.A.

J. W. Black, Research Institute, S.K.F. Ltd, Welwyn, Herts., England.

T. B. Bolton, Department of Pharmacology, University of Oxford, Oxford OX1 3QT, England.

E. Bülbring, Physiological Laboratory, University of Oxford, Oxford OX1 3PT, England.

A. S. V. Burgen, National Institute for Medical Research, Mill Hill, London NW7 1AA, England.

J.-P. Changeux, Unité de Neurobiologie Moléculaire, Département de Biologie Moléculaire, Institut Pasteur, Paris 15e, France.

D. Colquhoun, Department of Physiology and Biochemistry, University of Southampton, Southampton SO9 3TU, England.

E. De Robertis, Instituto de Anatomía General y Embriología, Facultad de Medicina, Universidad de Buenos Aires, Buenos Aires, Argentina.

C. M. S. Fewtrell, Department of Physiology and Biochemistry, University of Southampton, Southampton SO9 3TU, England.

H. M. Gerschenfeld, Laboratoire de Neurobiologie, Ecole Normale Supérieure, 46, rue d'Ulm, Paris 5e, France.

B. L. Ginsborg, Department of Pharmacology, University of Edinburgh, Edinburgh, Scotland.

D. H. Jenkinson, Department of Pharmacology, University College London, London WC1E 6BT, England.

A. Karlin, Department of Neurology, College of Physicians and Surgeons, Columbia University, New York, N.Y. 10032, U.S.A.

B. Katz, Department of Biophysics, University College London, London WC1E 6BT, England.

J. S. Kehoe, Laboratoire de Neurobiologie, Ecole Normale Supérieure, 46, rue d'Ulm, Paris 5e, France.

G. A. Kerkut, Department of Physiology and Biochemistry, University of Southampton, Southampton SO9 3TU, England.

L. G. Magazanik, Sechenov Institute of Evolutionary Physiology and Biochemistry, Academy of Sciences of the USSR, Leningrad, Soviet Union.

R. D. O'Brien, Section of Neurobiology and Behavior, Cornell University, Ithaca, N.Y. 14850, U.S.A.

T. R. Podleski, Section of Neurobiology and Behavior, Cornell University, Ithaca, N.Y. 14850, U.S.A.

L. T. Potter, Department of Biophysics, University College London, London WC1E 6BT, England. 
H. P. Rang, Department of Physiology and Biochemistry, University of Southampton, Southampton SO9 3TU, England.

H. O. Schild, Department of Pharmacology, University College London, London WC1E 6BT, England.

S. J. Singer, Department of Biology, University of California at San Diego, La Jolla, California, U.S.A.

S. Thesleff, Institute of Pharmacology, University of Lund, Lund, Sweden. 